Document downloaded from:

http://hdl.handle.net/10251/160300

This paper must be cited as:

Peris-Ortiz, M.; García-Hurtado, D.; Devece Carañana, CA. (2019). Influence of the balanced scorecard on the science and innovation performance of Latin American universities. Knowledge Management Research \& Practice. 17(4):373-383.

https://doi.org/10.1080/14778238.2019.1569488

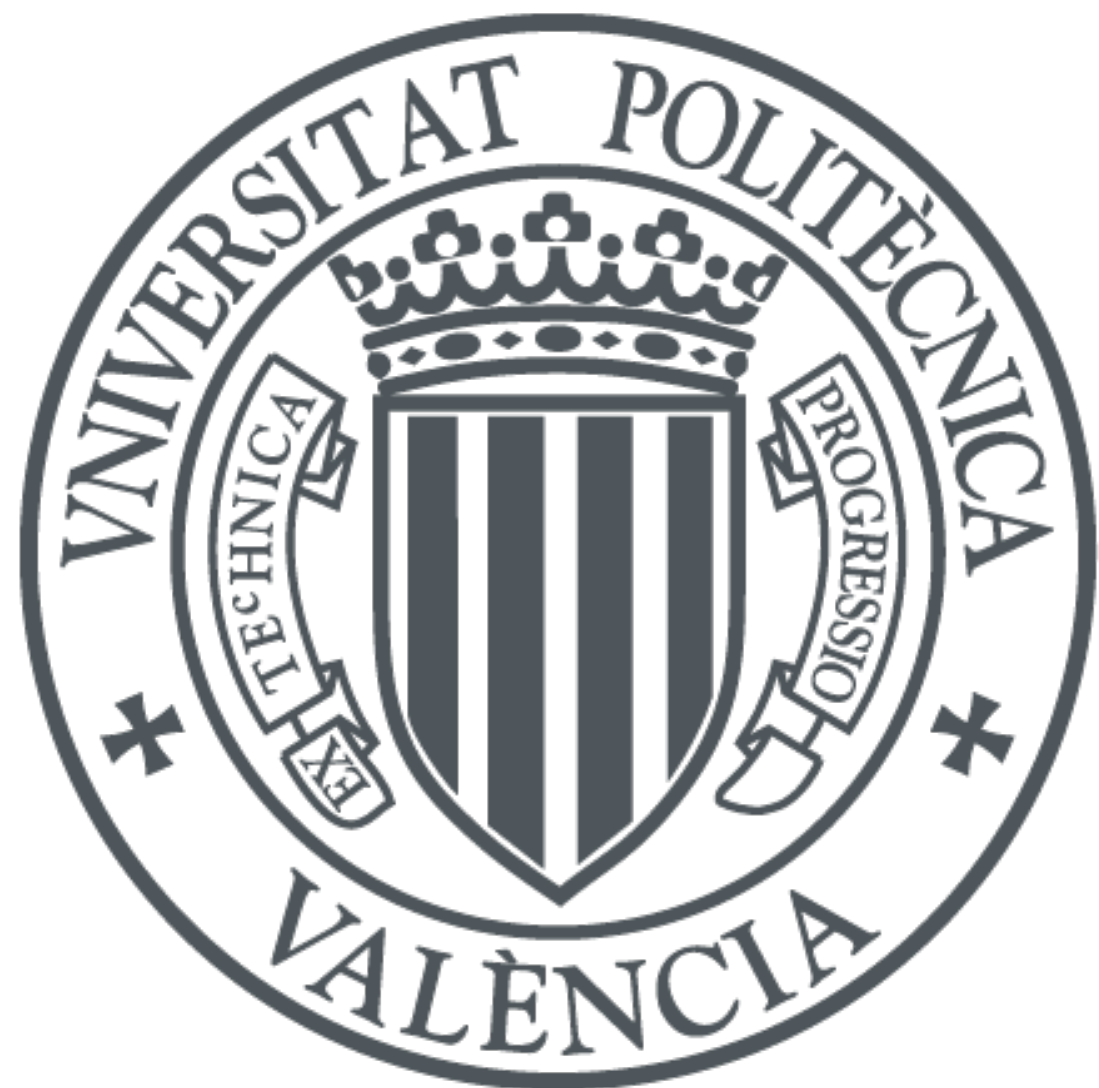

The final publication is available at

https://doi.org/10.1080/14778238.2019.1569488

Copyright Taylor \& Francis

Additional Information

This is an Accepted Manuscript of an article published by Taylor \& Francis in Knowledge Management Research \& Practice on 2019, available online: http://www.tandfonline.com/10.1080/14778238.2019.1569488 


\title{
The influence of the balanced scorecard on the science and innovation performance of Latin American universities
}

Marta Peris-Ortiz, Dayanis García-Hurtado \& Carlos Devece

\begin{abstract}
Pressure on the education system to meet society's needs has led some universities to adopt organisational performance measurement systems as strategic control tools. One of the most commonly used systems in business is the balanced scorecard (BSC). For Latin American universities, the urgent task of increasing the quantity and quality of research and innovation has led these universities to update their essential processes. A suitable control system is necessary to ensure the effectiveness of these new policies. Based on strategic management theory, this study focuses on the implementation of a BSC method in Latin American public universities. The aim of this study is to determine the influence of BSC implementation on universities' research and innovation performance. The results reveal similar patterns of indicators to measure performance in public universities. Furthermore, these indicators develop favourably following implementation of the BSC.
\end{abstract}

\section{Keywords}

Management indicators, balanced scorecard, higher education, research, innovation, Latin America, public universities. 


\section{Introduction}

In today's international context, the demands and challenges of the education system require new solutions. Organisations need staff who have the capacity to think, create, innovate and learn, and universities must play a fundamental role in the development of these capabilities (Damian, Montes, \& Arellano, 2010). The objectives of higher education have evolved over the years, but a central mission has always been to help people develop, supporting their integration into society so that they can shape the socioeconomic conditions of their environment.

The fundamental role of higher education is based on the development of strategies that enable economic and social progress. Society is transformed by universities. Universities drive economic growth as well as generating knowledge, which has traditionally been their basic mission in the past (Philbin, 2008). Today, the constant interaction between universities and their environment is essential for research and innovation. Recently, substantial changes have taken place in all industries. Rapid development of technology and intense global competition have transformed the competitive environment. These changes represent a continual challenge for the education sector, which must stay at the forefront of key areas in each industry through university degree programmes (Ankrah \& Al-tabbaa, 2017).

The growing need to improve the education system to adapt to current industry demands has led to the implementation of organisational performance measurement systems as strategic control tools. One of the most common strategic control tools is the balanced scorecard (BSC), developed by Kaplan and Norton (Kaplan \& Norton, 1992). Spender (2014) notes that the BSC has been implemented in more than half of the world's leading companies. The conceptual framework of this system has shifted. It is applied in lucrative and non-profit organisations, including government agencies and universities (Niven, 2008). The goal of the BSC is to overcome the shortcomings of traditional performance measurement systems, which consider solely financial performance (Pietrzak, Paliszkiewicz \& Klepacki, 2015).

In Latin American countries, the higher education sector grew considerably between 1950 and 2000. The number of higher education institutions (HEls) increased from 75 to 1500 , with an enrolment of almost 12 million students. Given this growth, HEls must deal with new challenges. They also face the urgent task of increasing the quantity and quality of research and innovation to respond to the challenges that face businesses and guarantee the effectiveness of essential university processes. By implementing the BSC, many Latin American universities have defined management indicators that allow them 
to translate their science and innovation visions into objective performance values. The BSC substantially improves HEIs' science and innovation performance, enabling them to align their strategic objectives with each key outcome area and support unit.

The objective of this research is to determine the influence of BSC implementation on the research and innovation performance of Latin American universities. The findings are based on data from interviews with managers at the universities selected for the study. Key information was also gathered from organisational documentation on strategic design. In the next section, the theoretical underpinnings of the research are addressed across four areas: strategic control systems (SCSs) and performance measurement, the BSC as a performance measurement system, application of the BSC in the public sector and management indicators as a starting point for control. Next, the method is described, empirical results are discussed and conclusions are presented.

\section{Theoretical framework}

\section{Strategic control systems and performance measurement}

Strategic control is a critical component of a strategic management approach. Specifically, it monitors and evaluates the effective implementation of a strategy. SCSs are defined as the routines and formal procedures that, with the support of information systems, are used by management to maintain or alter policy patterns in organisational activities (Bernard, 1968). SCSs are generally seen as necessary tools for implementing a strategy. Control systems also play a key role in the sanctions and rewards that influence employee behaviour. In general, SCSs coordinate employees' efforts, motivate managers and alter the strategy depending on the circumstances. They can provide a means to evaluate the development of the organisation, specify the relationship between investment and profitability, implement individual improvement actions and ensure that managers know when organisational performance is deteriorating and corrective measures are needed (Liviu, Sorina, \& Radu, 2008).

In the last two decades, conventional performance SCSs have been considered insufficient to accurately measure firm performance (Ridwan, Harun, An, \& Fahmid, 2013). Due to constantly changing environmental conditions, the approach towards performance control systems has changed from a purely financial approach to an approach based on the use of non-financial performance measures. Such measures play a fundamental role in formulating and implementing a strategy, and they are linked to the achievement of strategic goals. Thus, current approaches to effective strategic control are based on the use of non-financial measures (Langfield, 1997). However, most 
studies address performance control systems from an accounting perspective (Kraus \& Lind, 2010; Broadbent \& Laughlin, 2009; Ittner, Larcker, \& Randall, 2003).

One SCS component is the performance measurement system. This system is structured according to a set of metrics focused on quantifying actions (Neely, Mike, \& Platts, 1995). Ferreira and Otley (2009) provide a more comprehensive definition. They define an SCS as the group of mechanisms and processes used to identify the key objectives and support for implementation, planning, measurement, control, rewarding and learning. Pritchard, Roth, Jones, and Roth (1990) define performance measures as numerical or quantitative indicators that show how well each objective is met. Neely et al. (1995) define an SCS as the process of quantifying action, where measurement is the process of quantification and action leads to performance.

Tangen (2005) defines a successful performance measurement system as a set of performance measures (i.e. a metric used to quantify the efficiency and effectiveness of the action) that provides the company with useful information that helps manage, control, plan and carry out company activities.

\section{The balanced scorecard as a performance measurement system}

One of the most commonly used performance measurement systems is the BSC. The BSC is a key current approach not only because it covers both financial and non-financial measures, but also because of the design and implementation of the strategy (Wiersma, 2009).

The BSC was introduced in 1991 by Kaplan and Norton to strengthen traditional financial measures with complementary criteria that measure performance from three additional perspectives: customer opinions, internal business processes, and learning and growth (Kaplan \& Norton, 1996). Olve, Roy, and Wetter (2002) affirm that the BSC is used for strategic control and that it provides a valuable tool for employees to understand the company's situation, furnishing useful information to continuously develop specific control indicators that enable the company to reach its goals more quickly.

Applying the BSC enables alignment of management teams, business units, human resources, information technology and financial resources with organisational strategy. Although each organisation addresses challenges in different ways, at different paces and with different consequences, five common principles should be considered. BSC implementation should be based on these five principles (Kaplan \& Norton, 2001): translate the strategy into operational terms, align the organisation with the strategy, 
make strategy the daily work of the whole company, make strategy a continuous process and mobilise change through the leadership of managers.

\section{Application of the balanced scorecard in the public sector}

Applying BSC principles in the public sector poses a major challenge because of the unique circumstances of public administrations, which require adjustments in design and implementation (Gadenne \& Sharma, 2009). Nevertheless, it is believed that the use of accounting or performance management systems from commercial practices could improve decision-making processes, performance measurement systems and the financial and non-financial indicators used in the public sector (Northcott, Llewellyn, \& Kober, 2008).

Universities, which form part of the public sector, have adopted the BSC to improve their performance and meet challenges. The expansion of the education sector in the last 20 years has transformed universities into a major contributor to the economy, creating employment, improving the production infrastructure, increasing exports and contributing to the development of cities and regions (Al-Hosaini \& Sofian, 2015). However, HEls do not respond to technological development as fast as industry. Thus, universities may plan strategies without having a clear vision of the future and the issues afflicting the business environment (Briqa'an \& Alqurashi, 2012). Systems for measuring organisational performance have been adopted to avoid this misalignment. One of the most commonly used systems is the BSC (Kaplan \& Norton, 1992). HEls should establish accountability measures to link strategic objectives to their vision and mission, realign annual budgets and, most importantly, measure and monitor results in both the short and long term. All of these objectives can be achieved using the BSC.

Research has addressed the application of the BSC in HEls, considering non-profit organisations focused on customer satisfaction rather than profitability. Universities and HEls have adopted non-financial measures as the main BSC perspective. These measures respond better to their mission (Al-Hosaini \& Sofian, 2015). Some studies in this area have shown modifications in the use of conventional perspectives, adopting the customer perspective as the main one. Niven (2008) and Kaplan and Norton (1997) recommend a social perspective as the main output of public institutions.

The principles of BSC are based on the perspectives within which critical success factors are identified and a manageable number of management indicators are formulated. These indicators are aimed at the materialisation of critical success factors. Without abandoning the basic principles of the BSC, each HEI should establish management indicators that have a direct relationship with the organisation's vision because 
management indicators should reflect, in measurable terms, the aspirations expressed in the organisation's vision. The first principles proposed by Kaplan and Norton (1992) state that the BSC must convert the strategy into operational terms, providing a framework to describe and communicate a strategy in a consistent, measurable and clear way that is based on the aspirations contained in the vision.

Studies have evaluated the effectiveness of the BSC in HEls. For example, Al-Hosaini and Sofian (2015) reviewed studies that assessed the use of this method in universities, reporting the following:

As part of its contribution some benefits of using the BSC in HEls, namely, such as; determining priorities on future planning and needs assessment, providing a clear structure for continuous quality improvement, establishing a culture of Academic Quality among evaluating the efficient use of resources for each of the academic programs, and documenting the contribution of each activity towards the mission of the HEI so as to promote personal and academic excellence (Al-Hosaini \& Sofian, 2015, p. 33).

The BSC enables universities to convert strategy into action by monitoring management indicators of the performance measurement system (Franceschini \& Turina, 2013), which provides a basis for the establishment of a strategic planning system with management and control mechanisms (Markovic, Petkovic, Moljevic, Maric, \& Gojkovic, 2015). These actions help HEls position themselves in rankings and improve organisational performance. They also enable universities to adapt to changes in the environment and verify whether indicators are still suitable for controlling organisational performance (Pietrzak, Paliszkiewicz, \& Klepacki, 2015).

However, not all scholars consider this method suitable for HEls. Some universities have abandoned the BSC after it failed to meet expectations (Sayed, 2013). Lawrence and Sharma (2002) argue that applying the BSC in universities commodifies the science and innovation process. They report that the implementation of such a system turns universities into efficient companies, forcing them to adopt a capitalist viewpoint and overlook their principal function. The BSC nonetheless has considerable benefits. The innovation and learning perspective enables the university to identify flaws and develop strategies to correct them. Staff can thus develop better research practices, thereby raising the university's research profile. Chen, Ching-Chow Yang and Jiun-Yan Shiau (2006) argue that universities and non-profit institutions can learn from companies' administrative effectiveness to face competition in the higher education sector. 
One of the technical characteristics of designing a BSC is that managers must think in terms of management indicators. Such indicators cover financial as well as non-financial measures (Agostino \& Arnaboldi, 2012). Khalid, Knouzi, Tanane, and Talbi (2014) define an indicator as a relative value that assesses which activity participates in the completion of an objective. It enables the formalisation and fulfilment of contractual commitments and the implementation of control mechanisms.

A good indicator should be relevant, able to summarise information without distorting it, coordinated and structured (enabling it to be linked to other indicators for a thorough analysis of the system), accurate and comparable, reliable, and current (information must pertain to the present year) (Khalid et al., 2014).

An organisation's performance can be measured using indicators that reveal whether objectives are accomplished. Kaplan \& Norton (2000) consider that performance measures and the objectives for these measures are specific formulations of the company's strategy and that the actual results achieved for the various measures show how well the company succeeds in achieving these strategic choices.

Nowadays, the essence of a university is its ability to relate to and transform the environment. The university's processes must be aligned with this purpose. One essential activity that greatly helps resolve crucial business practice problems is research and innovation. Outside the 10 most developed countries, research is mostly carried out in public universities. Achieving interaction between university and industry is conducive to generating novel solutions, introducing new technology in companies and integrating the latent needs of the environment such as sustainable development (Al-ashaab, Flores, Magyar, \& Doultsinou, 2011).

Based on the formulation of strategic organisation, universities must pay special attention to establishing management indicators that enable performance measurement in the crucial university function of science and innovation.

Studies indicate that the most relevant research and innovation performance indicators are research projects, percentage of participation in research and research output. Securing publications in journals with high impact factors is also important (MohamadIshak, Suhaida, \& Yuzainee, 2009). Al-ashaab et al. (2011) identified the main research indicators, defined in the literature and supported by their research findings. These indicators correspond to those mentioned earlier, as well as the number of new products, services and technologies, and highlight the value of scientific collaboration between firms and industry for their mutual development. 
To investigate the previous statement, we performed a study of Latin American universities that have applied the BSC to manage their strategy. These universities were public and private institutions in four Latin American countries. The group of universities consisted of one university in Colombia, one in Chile, one in Peru and three in Cuba.

\section{Method}

\section{Research design}

Strategic management in HEls is difficult to study from a positivist perspective based on statistical inference because the strategies are developed in different contexts, and generalising the results is not always possible. One of the most commonly used methods in organisational studies is the case study, which enables analysis of phenomena in real contexts by simultaneously using multiple sources of evidence. Case studies can be based on quantitative and qualitative data (Yin, 2009). Case studies are widely recommended by researchers because of their advantages in complex areas such as management (Lee, Collier, \& Cullen, 2007; Gibbert, Ruigrok, \& Wicki, 2008; Villarreal \& Landeta, 2010; Dresch, Lacerda, \& Cauchick Miguel, 2015).

The study focused on six Latin American universities that conduct research in a range of contexts. These institutions have favourable positions in their country rankings, and they have implemented the BSC method for more than five years. We were therefore able to study the evolution in their performance. We interviewed university management, including Vice Chancellors for research and heads of strategic planning, who were more familiar with BSC implementation at their institutions.

\section{Data collection}

The research interview is a useful technique for obtaining data on the phenomena under study (Vallés, 1997). We used semi-structured interviews, where a script outlined the topics, although the interviewer was free to decide on the order of the items, ask other questions and discuss the issues in other terms. If necessary, the interviewer could ask the interviewee to go into greater depth on a certain topic (Corbetta, 2007).

We conducted semi-structured interviews with the Vice Chancellors for research and the heads of strategic planning. The questions were aimed at understanding the BSC implementation process and the way in which this process influences universities' research performance. We investigated aspects such as the alignment of strategic objectives with standardised indicators as a function of achieving a better position in international rankings. We asked interviewees to comment on their perceptions of 
positive changes following BSC implementation in general and, more specifically, in the area of science and innovation. We asked questions to determine the degree of alignment of strategic objectives with specific departmental and research group objectives, as well as researchers' individual objectives.

As an information gathering tool, document analysis was used. The advantages of document analysis include the low cost of obtaining a large amount of informative material, non-reactivity to the researcher's actions, exclusivity in providing information that would not otherwise be accessible and the possibility of lending a historical perspective to the study (Corbetta, 2007). Strategic institutional development plans, articles published in journals and other institutional documents were accessed to obtain the data.

The universities were selected according to the proposal outlined by Vallés (1997), who considers that the empirical sample for a qualitative study should not be selected based on statistical representation but rather conceptual relevance. The sample decision concerns the whole set of decisions regarding the selection of contexts, cases and dates. Accordingly, the recommended criteria for selecting qualitative samples are representativeness, heterogeneity and accessibility.

In this study, two fundamental aspects were considered when selecting the cases. First, the universities were from several Latin American countries with different contexts and degrees of development. Second, they had implemented the BSC to manage their strategies.

\section{Results}

As a general conclusion, the Latin American universities under study had adopted the BSC. For public sector institutions at the international level, use of the BSC has proved successful because of the need to improve their performance measurement systems. Analysis of BSC implementation in the studied HEls is presented below.

\section{Perspectives in Latin American higher education institutions}

The perspectives in the studied universities coincide for the public sector, where the trend is dominated by social aspects and the education and skills of students as the main output.

The establishment of perspectives was similar across the eight cases. Regardless of whether they are private or public, HEls focus on a non-financial social output. This coincides with the point raised by Niven (2008). According to this point, good financial results in the public sector are not necessarily a sign of success, which instead depends 
on contributing to society. The Cuban universities have a more conservative structure, consistent with the classical perspectives discussed by Kaplan and Norton. Their output is student focused. The other universities define different social customers such as students and the university community (Table 1).

Table 1. Scorecard perspective

\begin{tabular}{ll}
\hline IES & Perspective \\
\hline $\mathrm{A}$ & Customer, learning and growth, processes, financial \\
\hline $\mathrm{B}$ & User, internal processes, growth, material and financial resources \\
\hline $\mathrm{C}$ & User, internal processes, development, material and financial \\
& resources, human potential \\
\hline $\mathrm{D}$ & Student, external, internal, institutional development \\
\hline $\mathrm{E}$ & Resources, targets, internal processes, innovation and development \\
\hline $\mathrm{F}$ & University community, financial, processes, learning and growth \\
\hline
\end{tabular}

Table 2. Details of universities considered in the study

\begin{tabular}{|c|c|c|c|c|c|c|c|}
\hline \multirow[t]{2}{*}{ University } & \multirow{2}{*}{$\begin{array}{l}\text { Year } \\
\text { founded }\end{array}$} & \multirow[t]{2}{*}{ Faculty } & \multirow[t]{2}{*}{ Researchers } & \multirow[t]{2}{*}{ Degrees } & \multicolumn{3}{|c|}{ Postgraduate education } \\
\hline & & & & & $\mathrm{PhD}$ & Master's & Specialisations \\
\hline A & 1973 & 681 & $\mathrm{n} / \mathrm{d}$ & 14 & 4 & 20 & - \\
\hline B & 1952 & 1424 & 44 & 53 & 5 & 26 & - \\
\hline $\mathrm{C}$ & 1978 & 595 & 13 & 39 & 4 & 13 & 2 \\
\hline $\mathrm{D}$ & 1960 & 673 & 64 & 55 & 2 & 15 & 14 \\
\hline $\mathrm{E}$ & 1954 & 1485 & 250 & 64 & 12 & 40 & 43 \\
\hline $\mathrm{F}$ & 1980 & 482 & $\mathrm{n} / \mathrm{d}$ & 20 & 6 & 4 & - \\
\hline
\end{tabular}

\section{Management indicators in research and innovation}

The review of documents was used to identify the universities' research and innovation vision and main indicators. The vision is where the organisation states its shared aspirations for the future of science and innovation. Accordingly, numerous management indicators are observed from this perspective. The relationship between the universities' vision and indicators is presented below.

Table 3. Key elements of the science and innovation vision

A

B
Participation in networks, projects, high-impact publications and academic services are important. Priority is placed on doctoral programmes and the offer of flexible postgraduate programmes shaped by the new work environment, with active participation by the university in the local region supported by the use of IT.

We must achieve results in science, technology and university innovation linked to local aims. Together with the management of knowledge and innovation, this will have an impact and will contribute to the economic and social development of the region. 

the university can play a decisive role in the economic and social development of the Avilanian territory, with a marked impact on local development through a strategic alliance with local government.

D

To be an outstanding university with a culture of internationalisation and academic, research and technological leadership and an impact at the binational (Colombia and Venezuela), national and international levels through transparent, efficient and effective management. Academic research and technological leadership, where research becomes a key practice for the university's integral and innovative education.

E

To be an outstanding university committed to progress, well-being and sustainable development based on scientific and humanistic knowledge, technological advancement and artistic creation consistent with a path towards freedom, respect and pluralism.

$\mathrm{F}$

Major university in the south of Peru specialised in the comprehensive education of professionals, researchers and entrepreneurs with a socially responsible approach and accredited programmes.

Table 4. Main indicators to measure science and innovation performance

A 7 indicators. The most representative ones are displayed.

1. Satisfaction with research

2. Project structure

3. Awards

4. Publications by groups.

34 indicators. The most representative ones are displayed.

1. Recognised social and environmental impacts (total)

2. Internal system of industrial property

3. Patent applications in Cuba and abroad

4. Patents/trademarks granted in Cuba and abroad

5. Non-computer and computer registers

6. Project structure index

7. Number of international projects

8. Number of networks and scientific associations

9. National and international awards and recognitions

10. Articles published in group 1, 2, 3 and 4 journals

11. Publications of books in Cuba and abroad

12. Presentations at important international events

13. Position of the university in the Latin American ranking SCIMAGO-SCOPUS.

C

28 indicators. The most representative ones are displayed.

1. Number of projects submitted

2. Number of projects under execution

3. Number of projects linked to activity

4. Number of international projects

5. Revenue from commercialisation of products and services derived from R\&D

6. Number of national awards

7. Number of publications in different groups of journals

8. Total financing and resources collected based on projects for local development

9. Number of technologies introduced for local development.

65 indicators. The most representative ones are displayed.

1. Degree of effectiveness and efficiency of the management processes of research and innovation in the presentation of the project

2. Number of internal calls for research 
3. Degree of improvement of research groups

4. Number of scientific events

5. Number of projects presented and awarded by researchers per year

6. Percentage of improvement of the institutional indicators such as projects, publications and postgraduate programmes (created and accredited)

7. Quality and impact of the scientific production and innovation of the University

8. Number of national and international publications in categories A1, A2, B and C

9. Positioning of the university in the national and international level in the field of research and innovation

10. Number of projects in which international researchers participate

11. Degree of strengthening of the editorial processes of institutional journals and the production of books

12. Number of technological activities that allow the enhancement of research and innovation (e.g. publishing, fairs, etc.)

13. Number of registered patents

14. Number of registered pieces of software.

$\mathrm{E}$

6 indicators. All are displayed.

1. Number of proposed projects

2. Active centres with own or external financing

3. Publications with authors outside the university

4. Number of ISI publications

5. Number of patents

6. Number of innovation and entrepreneurship research initiatives between the university and business.

$\mathrm{F}$

10 indicators. The most representative ones are displayed.

1. Percentage of teachers who prepared publications in Scopus, Scielo or ISI

2. Percentage of teachers with published books

3. Number of patents registered by students, teachers and/or researchers

4. Percentage of agreements and active strategic alliances for research and academic development.

After analysing the proposal of indicators, we observe that numerous indicators are common to all cases. The number of research projects is the most common research and innovation indicator, followed by number of scientific publications and number of patents. Quality and impact, scientific production and innovation are indicators considered by most HEls. Financial income from the commercialisation of scientific output is similarly important.

\section{Research and innovation progress through the balanced scorecard}

One indicator that reflects the research progress of universities is the number of scientific publications included in prestigious databases. For the purposes of this research, we analysed the trend of publications in the Web of Science for the four years before and after implementation of the BSC.

Table 5 shows the publications by year, normalised with reference to year 0 (i.e. the year in which the BSC was first implemented). Universities D and E considerably improved their performance. University E maintained its steady improvement. Year 2016 is located 
amongst the four best years for the country in terms of this indicator. Notably, almost $50 \%$ of scientific articles published each year were co-written with researchers and institutions from other countries. This finding reflects the strong international character of the research. The remaining universities achieved positive results, although they did not achieve an increase.

Table 5. Web of Science publications over time

\begin{tabular}{|c|c|c|c|c|c|c|c|c|c|}
\hline & \multicolumn{4}{|c|}{ Pre-BSC } & \multirow{2}{*}{$\begin{array}{c}\text { Year } 0 \\
0\end{array}$} & \multicolumn{4}{|c|}{ Post-BSC } \\
\hline & -4 & -3 & -2 & -1 & & 1 & 2 & 3 & 4 \\
\hline \multicolumn{10}{|c|}{$\mathbf{A}$} \\
\hline B & $n / d$ & $n / d$ & 0.67 & 0.44 & $1^{\mathrm{b}}$ & 0.74 & 0.84 & 0.98 & 1.01 \\
\hline C & 0.46 & 0.80 & 1 & 1.53 & $1^{c}$ & 1.30 & 0.96 & 1.07 & 0.76 \\
\hline D & 1.93 & 1.56 & 1.25 & 1.62 & $1^{d}$ & 2.5 & 1.06 & 3.87 & 3.93 \\
\hline$E$ & 0.76 & 0.75 & 0.83 & 0.86 & $1^{e}$ & 1.11 & 1.58 & 1.63 & 1.90 \\
\hline $\mathbf{F}$ & & & & & & & & & \\
\hline
\end{tabular}

To complement the data provided by the universities, we used the 2013, 2015, 2017 and 2018 editions of the SIR Iber (SCImago Institutions Rankings). The SIR Iber measures the research activity of Ibero-American HEls. Figure 1 shows the increase in publications indexed in Scopus by institution. The trend was favourable in all universities included in the study.

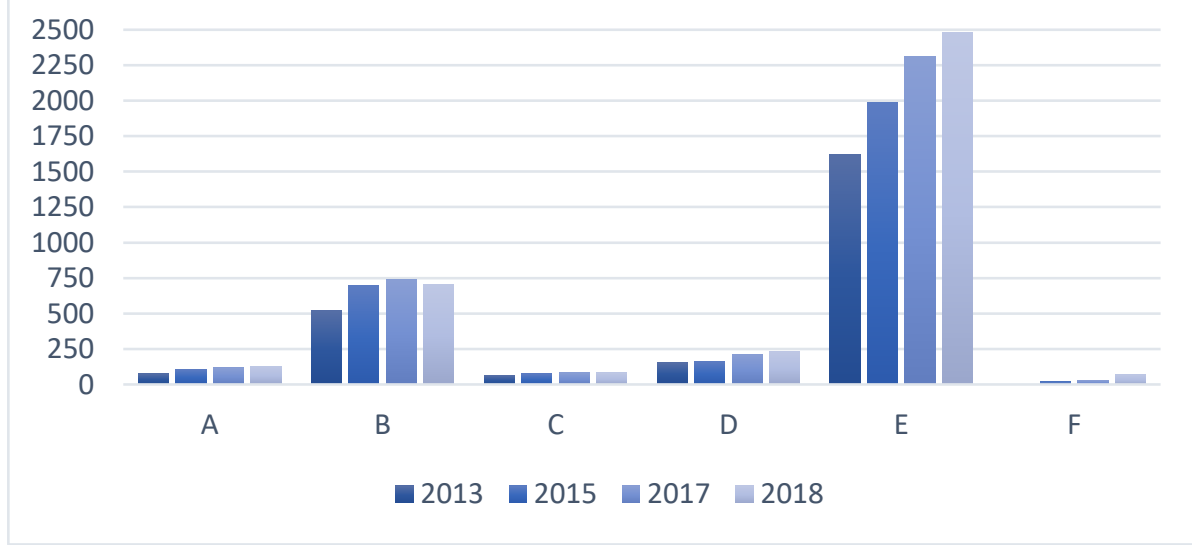

Figure 1: Progress in the number of publications indexed in Scopus by institution.

Source: SCImago Institutions Rankings

\section{Research projects}

Research projects are important for the scientific growth of the universities in the sample. These universities have clearly defined strategic objectives based on increasing the number of research projects. In the strategic map of each university, we can observe the 
perspectives and strategic objectives visually represented as a cause-effect relationship. In summary, we present those related to research projects. These were gathered from the strategic development plans of each university.

- Increase the awarding of projects with greater complexity and scope (E).

- Promote, increase and strengthen intellectual production, academic research, and projects based on social responsibility and university internationalisation $(F)$.

- Increase output of research, development and management of innovation (C).

- Research, technology and innovation development (D).

- Increase the results of R\&D and innovation management (B).

Table 6. Progress in research projects

\begin{tabular}{|c|c|c|c|c|c|c|c|c|c|}
\hline & \multicolumn{4}{|c|}{ Pre-BSC } & \multicolumn{2}{|l|}{ Year 0} & \multicolumn{2}{|c|}{ Post-BSC } & \multirow[b]{2}{*}{4} \\
\hline & -4 & -3 & -2 & -1 & 0 & 1 & 2 & 3 & \\
\hline \multicolumn{10}{|c|}{$\mathbf{A}$} \\
\hline B & $n / d$ & $n / d$ & $n / d$ & $n / d$ & $1^{b}$ & 1.01 & 0.96 & 0.86 & 0.90 \\
\hline C & 2.95 & 1.91 & 4.17 & 1.80 & $1^{c}$ & 1.69 & 1.73 & 2.43 & 3.65 \\
\hline D & $\mathrm{n} / \mathrm{d}$ & $n / d$ & 4.00 & 4.40 & $1^{d}$ & 2.95 & 3.09 & $n / d$ & 3.36 \\
\hline $\mathbf{E}$ & $n / d$ & $\mathrm{n} / \mathrm{d}$ & $\mathrm{n} / \mathrm{d}$ & $\mathrm{n} / \mathrm{d}$ & $1^{\mathrm{e}}$ & 1.64 & 1.80 & 1.78 & 1.55 \\
\hline $\mathbf{F}$ & $n / d$ & $n / d$ & $n / d$ & $n / d$ & $1^{f}$ & 4.6 & 5.33 & 6.00 & 4.33 \\
\hline
\end{tabular}

Since implementing the BSC, university $F$ has substantially increased its number of research projects. Notably, university $F$ is not amongst the country's most favoured universities in terms of researchers. There are 1.46 researchers per 1,000 inhabitants, whereas in the nation's capital, this ratio is 8.79 per 1,000 inhabitants. Despite the low rate of researchers with respect to other regions, the university still performed well in recent years.

University D has not witnessed a significant increase in its number of projects. However, other key indicators on the BSC have increased significantly. According to the university management, "certain indicators measure performance in this area, including increase in number of research groups, mobility and new publications". The behaviour of the research groups increased favourably. There were 54 groups one year before introducing the BSC method. Five years after its introduction, there were 140 groups.

The number of patents reflects a university's capacity to innovate and create new technology. The 2018 edition of the SIR Iber includes a new indicator in the innovation factor. This indicator relates to the number of patents applied for by universities between 
2012 and 2016. This indicator depends largely on the size of the university. Of the six cases considered in this study, only A, B and E applied for patents. University E applied for six patents, whereas universities $A$ and $B$ applied for one.

\section{Progress in international rankings}

The scientific and innovation development of universities has multiple causes. Not only does an effective performance measurement system have an influence, but environmental conditions that enable institutions to conduct their research also play a role. These conditions include low industrial density, weak systems of production, low national GDP and poor infrastructures. The universities examined in this study also have to deal with unfavourable environmental conditions. Therefore, their science and innovation performance is affected by these conditions.

Notably, not all Latin American universities focus on research. The largest universities and the public universities generate the greatest science and innovation output (UNESCO, 2015). The universities considered in this study are not amongst the major universities in their countries.

Figure 2 shows the progress of the cases under study in the SIR Iber ranking, which reflects scientific activity in Spain, Portugal and Latin America only.

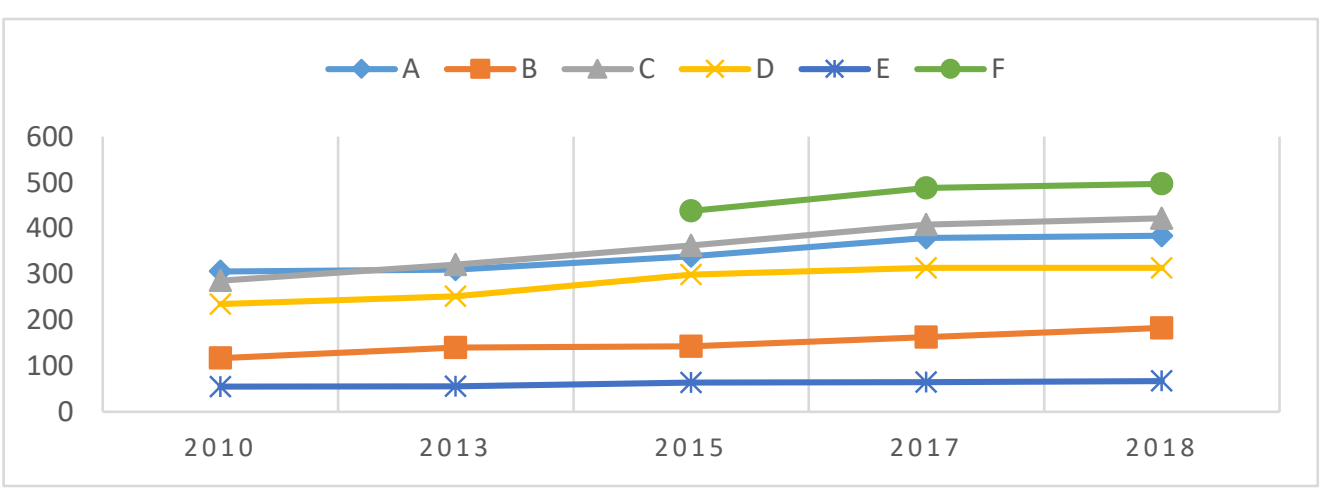

Figure 2: Progress of HEls in international rankings

Source: SCImago Institutions Rankings

The trend was negative for most universities. However, this does not mean that the performance measurement system is ineffective but rather that it is based on the aforementioned factors. Notably, scientific production in Latin America is concentrated in the main universities in each country. The oldest and largest universities are responsible for around $50 \%$ of studies (Altbach, Reisberg, \& Rumbley, 2009).

University E, the largest university studied in this research, has the greatest scientific and innovation potential and is one of the top universities in the country. This university held its position in the ranking and has increased its score for the remaining indicators 
analysed in this study. The smallest universities and those with the least scientific and innovation production were affected by the competition as regards their position in the ranking. Even so, they had positive results. For example, university $F$ was included in the 2015 edition of the ranking. In the 2015 edition, results for 2009 to 2015 were considered, showing that from this date, the university began to have significant performance in research and innovation. In the classification of universities from this country, the AméricaEconomia journal ranking is noteworthy. This ranking is based on criteria such as teaching quality, research, accreditation, internationalisation and agreements. University $F$ is placed $17^{\text {th }}$ in this ranking, which reflects favourable progress, considering that in 2013 , the university was in $43^{\text {rd }}$ place.

\section{The balanced scorecard encourages strategic alignment in higher education institutions}

Aligning the organisation is a key factor to achieve strategic control. The performance indicators should be consistent with the vision. In this regard, there is evidence of a relationship between the results achieved and the HEls that have aligned their strategy.

The universities under study have focused their efforts on aligning the strategy with the university's specific objectives and researchers' individual objectives. Doing so enables them to measure actual research performance. As the management at university $\mathrm{C}$ explains,

"Achieving alignment of strategic objectives with specific objectives and personal objectives makes it possible to properly evaluate performance and bring the entire organisation together to work towards the same objective, which should lead to better outcomes."

Translating the vision into operational terms is fundamental for universities, which have been affected in terms of performance in a range of areas. University $D$ faced this problem. Therefore, in 2012, the university redesigned its strategy and began to employ the BSC. Reports on this institution refer to the high effectiveness of the BSC for HEIs, enabling universities to address a systematic process through which the institution engages all of its members in the improvement of its organisational effectiveness and the establishment of a relationship between its vision and the indicators used. As the university management explains,

"The indicators are aligned with the mission. The indicators are aimed at the three axes of the mission and the financial considerations. The structure of the BSC 
enables alignment with the organisation and a focus on the accreditation of the quality of the processes."

Institution B has implemented BSC. The management reports that the performance indicators enable the measurement and monitoring of how the processes are oriented towards fulfilling the university's mission or objectives, providing insight into the progress and trends of the processes as well as the planning of target values.

University E reports that since 2007, it has managed its strategy under the paradigm of strategic alignment (Kaplan \& Norton, 2006). In this stage, emphasis is placed on aligning the four perspectives of BSC defined by the institution with the proposed vision, which translates into significant results. This university perfected the implementation of the BSC more than 10 years ago, so it has favourable long-term performance.

\section{Conclusions}

The BSC is a useful tool for controlling the multidimensional performance of universities. In research and innovation, the results of the adopted initiatives are usually appreciated in the long term. The complexity of such activities calls for an integrated approach. The implementation of the BSC entails identification of the key success factors of innovation and research activities and a cause-effect reasoning that can be extremely helpful in promoting continuous improvement. The BSC is an important tool that can be used to create strategies and monitor organisational performance, continually comparing this with key elements from the strategic plan (Al-Hosaini \& Sofian, 2015).

The link between university and business is an essential element in the development of Latin American countries. In the process of scientific research and innovation, universities are key institutions for the resolution of countless problems in business and industry. Management indicators are increasingly used to measure universities' science and innovation performance in Latin American countries. According to the cases considered in this study, the common indicators relate to the execution of projects, visibility of research results through publication in high-impact journals, and revenues from the sale of licensed products, registrations and patents.

The use of the BSC has led to considerable advances in the performance of the universities considered in this study, essentially because the evaluation, promotion and remuneration system is based on these indicators. The transparency of the evaluation and the objectivity of the indicators mean that researchers can align their objectives with those of their affiliated institutions. These findings are consistent with those reported by 
Pietrzak et al. (2015), who referred to the benefits of a well-designed, up-to-date BSC model that helps improve university performance.

It is difficult to assess whether these results are actually transferred to society and whether the technology transfer to the private sector improves the competitiveness of companies in the region. The positive results of specific projects in the private sector are nonetheless encouraging.

\section{References}

Agostino, D., \& Arnaboldi, M. (2012). Design issues in Balanced Scorecards: The " what "' and " how" of control. European Management Journal, 30, 327339. doi:10.1016/j.emj.2012.02.001

Al-ashaab, A., Flores, M., Magyar, A., \& Doultsinou, A. (2011). A Balanced Scorecard for Measuring the Impact of Industry- University Collaboration. Production Planning and Control, 22(5-6), 554-570.

Al-Hosaini, F., \& Sofian, S. (2015). A Review of Balanced Scorecard Framework in Higher Education Institution (HEls). International Review of Management and Marketing, 5(1), 26-35.

Altbach, P. G., Reisberg, L., \& Rumbley, L. E. (2009). Trends in Global Higher Education: Trackingan Academic Revolution. Paris: UNESCO.

Ankrah, S., \& Al-tabbaa, O. (2017). Universities - industry collaboration: A systematic review ScienceDirect. Scandinavian Journal of Management, 31(3), 387-408. doi:10.1016/j.scaman.2015.02.003

Bernard, C. (1968). The functions of the executive. United States: Harvard Univ Press.

Briqa'an, A. M. ., \& Alqurashi, A. A. (2012). Governance and role of universities in the face of challenges. In Paper presented at the International Scientific Conference. Lebanon.

Broadbent, J., \& Laughlin, R. (2009). Performance management systems: A conceptual model. Management Accounting Research, 20, 283-295.

Chen, S.-H., Ching-Chow Yang, C.-C., \& Jiun-Yan Shiau, J.-Y. (2006). The application of balanced scorecard in the performance evaluation of higher education. The TQM Magazine, 18(2), 190-205. doi:doi.org/10.1108/09544780610647892

Corbetta, P. (2007). Metodología y técnicas de investigación social. Madrid: McGraw Hill.

Damian, J., Montes, E., \& Arellano, L. (2010). Los estudios de opinión de empleadores. Estrategia para elevar la calidad de la educación superior no 
universitaria. REICE. Revista Iberoamericana Sobre Calidad, Eficacia Y Cambio En Educación, 8(3), 180-203.

Dresch, A., Lacerda, D. P., \& Cauchick Miguel, P. . (2015). A Distinctive Analysis of Case Study, Action Research and Design Science Research. Revista Brasileira De Gestão De Negócios, 17(56), 1116-1133.

Ferreira, A., \& Otley, D. (2009). The design and use of performance management systems: An extended framework for analysis. Management Accounting Research, 20, 263-282.

Franceschini, F., \& Turina, E. (2013). Quality improvement and redesign of performance measurement systems: An application to the academic field. Quality and Quantity, 47(1). doi:10.1007/s11135-011-9530-1

Gadenne, D., \& Sharma, B. (2009). Balanced Scorecard Implementation in the Public Sector: Lessons Learnt in a Large Local Government Authority. In Presented at AFAANZ conference. Retrieved from http://www.afaanz.org/openconf/2009/modules/request.php?module=oc_pr oceedings\&action=view.php\&a $=$ Accept+as+Forum\&id=228

Gibbert, M., Ruigrok, W., \& Wicki, B. (2008). What passes as a rigorous case study? Strategic GManagement Journal, 29(3), 1465-1474.

Ittner, C. D., Larcker, D. F., \& Randall, T. (2003). Performance implications of strategic performance measurement in financial services firms. Accounting, Organizations and Society, 28, 715-741.

Kaplan, R. ., \& Norton, D. . (1996). Using the Balanced Scorecard as a Strategic Management System. Harvard Business Review, (January-February), 7585.

Kaplan, R. ., \& Norton, D. . (2000). Having trouble with your strategy? Then map it. Harvard Business Review, 78(5), 167-178.

Kaplan, R. S., \& Norton, D. P. (1992). The Balanced Scorecard - Measures that Drive Perfromance. Harvard Business Review, 70(1), 71-79.

Kaplan, R. S., \& Norton, D. P. (2001). Transforming the Balanced Scorecard from Performance Measurement to Strategic Management: Part II. Accounting Horizons, 15(2), 147-160.

Kaplan, R. S., \& Norton, D. P. (2006). Alignment: Using the Balanced Scorecard to Create Corporate Synergies (Harvard Bu.). Boston.

Khalid, S., Knouzi, N., Tanane, O., \& Talbi, M. (2014). Balanced scoreboard, the performance tool in higher education: Establishment of performance indicators. Procedia Social and Behavioral Sciences, 116, 4552-4558. doi:10.1016/j.sbspro.2014.01.984 
Kraus, K., \& Lind, J. (2010). The impact of the corporate balanced scorecard on corporate control - A research note. Management Accounting Research, 21, 265-267. doi:10.1016/j.mar.2010.08.001

Langfield, K. (1997). Management control systems and strategy: A critical review. Accounting, Organizations and Society, 22(2), 207-232.

Lawrence, S., \& Sharma, U. (2002). Commodification of Education and Academic LABOUR - Using the Balanced Scorecard in a University Setting. Critical Perspectives on Accounting, 13(October), 661-677. doi:10.1006/cpac.2002.0562

Lee, B., Collier, P., \& Cullen, J. (2007). Reflections on the use of case studies in the accounting, management and organizational disciplines. Qualitative Research in Organizations and Management: An International Journal, 2(3), 169-178.

Liviu, C., Sorina, G., \& Radu, O. (2008). Strategic control and the performance measurement systems. Annals of the University of Oradea, Economic Science Series, 17(4), 189-194.

Markovic, N., Petkovic, D., Moljevic, S., Maric, B., \& Gojkovic, R. (2015). Possibilities of implementation of the Balanced Scorecard Method in Higher Education. In pendiente a buscrarrrrr.

Mohamad-Ishak, M. ., Suhaida, M. . S. ., \& Yuzainee, M. . Y. . (2009). Performance measurement indicators for academic staff in Malaysia Private Heigher Education Institutions: A case study in INITEN. In Performance Measurement Association Conference PMA 2009. University of Otago, New Zealand.

Neely, A., Mike, G., \& Platts, K. (1995). Performance measurement system design: a literature review and research agenda. International Journal of Operations \& Production Management, 15(4), 80-116.

Niven, P. R. (2008). Balanced Scorecard Step-by-Step for Government and Nonprofit Agencies. Hoboken NJ: John Wiley \& Sons Inc.

Northcott, D., Llewellyn, S., \& Kober, R. (2008). Testing the cause effect of the relationships in a public sector balanced scorecard. In Presented at AFFAAN Conference. Sydney.

Olve, N. G., Roy, J., \& Wetter, M. (2002). Implantando y Gestionando el Cuadro de Mando Integral (Editorial .). Barcelona. España. 2002.

Philbin, S. (2008). Process model for university-industry research collaboration. European Journal of Innovation Management, 11, 488-521.

Pietrzak, M., Paliszkiewicz, J., \& Klepacki, B. (2015). The application of the balanced scorecard ( BSC) in the higher education setting of a Polish 
university. Online Journal of Applied Knowledge Management, 3(1), 151164.

Pritchard, R. D., Roth, P. ., Jones, S. ., \& Roth, P. G. (1990). Implementing feedback systems to enhance productivity: a practical guide. National Productivity Review, 10(1), 57-67.

Ridwan, R., Harun, H., An, Y., \& Fahmid, I. M. (2013). The Impact of the Balanced Scorecard on Corporate Performance: The Case of an Australian Public Sector Enterprise. International Business Research, 6(10), 103-110. doi:10.5539/ibr.v6n10p103

Sayed, N. (2013). Ratify, reject or revise : balanced scorecard and universities. International Journal of Educational Management, 27(3), 203-220. doi:10.1108/09513541311306440

Spender, J. C. (2014). Business Strategy. Managing Uncertainty, Opportunity, \& Enterprise,. Oxford, Oxford University Press.

Tangen, S. (2005). Insights from practice: Analyzing the requirements of performance measurement systems. Measuring Business Excellence, 9(4), 46-54.

UNESCO. (2015). América Latina y el Caribe. Revisión Regional 2015 de la Educación para Todos. Retrieved from http://unesdoc.unesco.org/images/0023/002327/232701s.pdf

Vallés, M. (1997). Técnicas cualitativas de investigación social. Reflexión metodológica y práctica profesional. Editorial Síntesis.

Villarreal, O., \& Landeta, J. (2010). El estudio de casos como metodología de investigación científica en dirección y economía de la empresa. Una aplicación a la internacionalización. Investigaciones Europeas de Dirección Y Economía de La Empresa, 16(3), 31-52.

Wiersma, E. (2009). For which purposes do managers use Balanced Scorecards? An empirical study. Manegement Accounting Research, 20, 239-251. doi:10.1016/j.mar.2009.06.001

Yin, R. K. (2009). Case Study Research: Design and Methods (4th ed.). Newbury Park, CA: Sage. 